\title{
DÜBLIN
}

Technological University Dublin

ARROW@TU Dublin

2007-01-01

\section{Investigation on Proximity-coupled Microstrip Integrated PV Antenna}

\author{
Maria Roo Ons \\ Technological University Dublin
}

S. Shynu

Technological University Dublin

Max Ammann

Technological University Dublin, max.ammann@tudublin.ie

See next page for additional authors

Follow this and additional works at: https://arrow.tudublin.ie/engschececon

Part of the Electrical and Computer Engineering Commons

\section{Recommended Citation}

Ons, M., Shynu, S., Ammann, M., McCormack, S., Norton, B.: Investigation on proximity-coupled microstrip integrated PV antenna. EuCAP 2007: The Second European Conference on Antennas and Propagation, Edinburgh, 11-16 November, 2007.

This Conference Paper is brought to you for free and open access by the School of Electrical and Electronic Engineering at ARROW@TU Dublin. It has been accepted for inclusion in Conference papers by an authorized administrator of ARROW@TU Dublin. For more information, please contact arrow.admin@tudublin.ie, aisling.coyne@tudublin.ie,gerard.connolly@tudublin.ie. Funder: Science Foundation Ireland

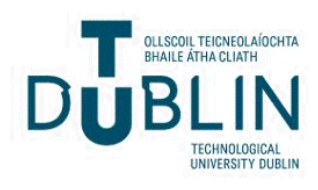


Authors

Maria Roo Ons, S. Shynu, Max Ammann, Sarah McCormack, and Brian Norton

This conference paper is available at ARROW@TU Dublin: https://arrow.tudublin.ie/engschececon/30 


\title{
INVESTIGATION ON PROXIMITY-COUPLED MICROSTRIP INTEGRATED PV ANTENNA
}

\author{
M.J. Roo Ons*, S.V. Shynu*, M.J. Ammann*, S. McCormack ${ }^{\dagger}$, B. Norton ${ }^{\dagger}$ \\ * School of Electronic \& Communications Engineering, Dublin Institute of Technology, Ireland. \\ mariajose.rooons@student.dit.ie \\ ${ }^{\dagger}$ Dublin Energy Lab, Focas Institute, Dublin Institute of Technology, Ireland
}

Keywords: Solar cell, ground plane, proximity-coupling, microstrip antenna.

\section{Antenna design}

\begin{abstract}
The use of polycrystalline silicon solar cells $(156 \times 156 \mathrm{~mm})$ as a groundplane for a proximity-coupled microstrip square patch antenna $(30 \times 30 \mathrm{~mm})$ is investigated. Four different models that arise from the different possible positions of the cell with respect to patch, were simulated, fabricated and compared to an ideal PEC ground plane antenna of the same size. It was found that the use of the solar cell as ground plane is feasible, yielding similar impedance bandwidth (around $4 \%, 3.5 \%$ for the PEC) with reasonable gain. The feasibility of using poly-crystalline solar cells as a ground plane, instead of a PEC is examined for proximity coupled patch antennas.
\end{abstract}

\section{Introduction}

The combination of antenna technology with solar panels has previously focussed on satellite communications, where antennas and solar cells compete for the same scarce surface space. The breakthrough to commercial applications is now possible due to the continuous development of new materials with improved efficiency, with their increased application driving costs down.

In the first reported approach of integration commercial solar cells were merely placed next to a microstrip patch antenna [1]. In the case of patch antennas, the cells cannot be too close to the radiating edges due to performance degradation.

The development of the thin amorphous silicon on polymer substrate solar cell technology made it possible to easily cut and fit the solar cells to various shapes such as slot antennas, leading to optimised use of the available area, without affecting the radiating characteristics of the antenna [2].

Other attempts to integrate solar cells with antennas take advantage of the fact that each solar cell has a homogeneous conductive rear side contact to collect the DC current, which can be used as a radiating element itself [3].

In this paper the use of standard low-cost multi-crystalline silicon solar cells as the ground plane for proximity-coupled microstrip patch antennas is investigated.
The design employs polycrystalline silicon Solland solar cells, which are $156 \mathrm{~mm} \times 156 \mathrm{~mm}$ in size, with an average thickness of $0.26 \mathrm{~mm}$. The rear-side is covered with a thin homogeneous aluminium layer, while the front side is grided with $0.2 \mathrm{~mm}$ wide silver bus bars, spaced $2.732 \mathrm{~mm}$ over the silicon layer.

A detailed layout of the proposed integrated solar antenna is illustrated in Figures 1. It can be seen that the solar cell replaces the standard PEC ground plane of a proximitycoupled fed microstrip antenna. Both radiating patch and 50 ohm transmission line were fabricated on a low-cost FR-4 substrate with $1.52 \mathrm{~mm}$ thickness and a dielectric constant of 4.3. The patch is $30 \mathrm{~mm}$ square and centred over the ground plane.

It can be observed that the solar cell in the Figure 1 is deployed in its three main layers for a better understanding of its internal structure. The whole cell is not much thicker than the copper coat of most standard microwave boards. The aluminium back contact layer has a thickness of $35.71 \mu \mathrm{m}$, the silicon $n^{+}-p-p^{+}$doped layer is of $210,23 \mu \mathrm{m}$, and the thick of the silver bars for the DC collection is estimated in 17.62 $\mu \mathrm{m}$.

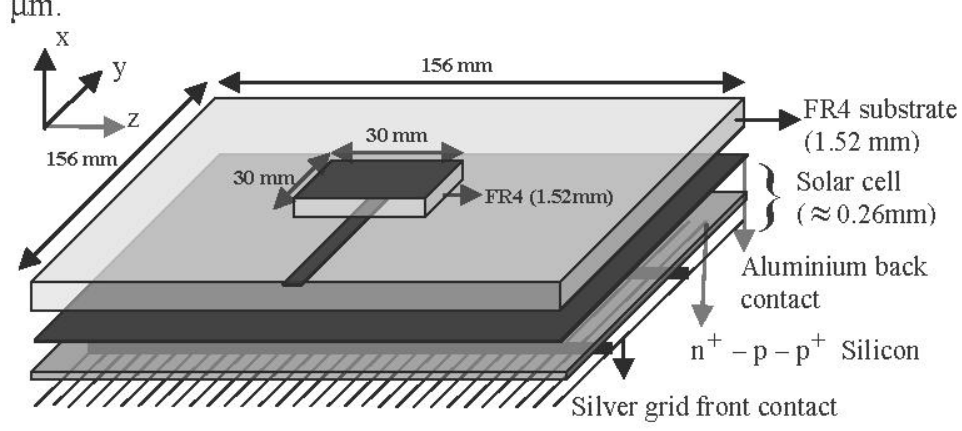

Figure 1. Exploded view of the proposed proximity-coupled fed microstrip integrated PV antenna with dimensions.

Four different models were investigated, with different solar cell and silver grid orientations with respect to the patch, and they are compared with the ideal PEC antenna. In Figure 1 the cell is placed with its aluminium back contact attached to 
the FR4 substrate, and with the silver grid lines oriented parallel to the feed line, and therefore parallel to the resultant E-field. But three more positions are possible for the cell as ground plane for the antenna.

The rear side of the four possible prototypes were captioned, shown in Figure 2 and named Prototypes A, B, C and D respectively. It can be observed that the position of the cell used in Figure 1 corresponds with Prototype B.

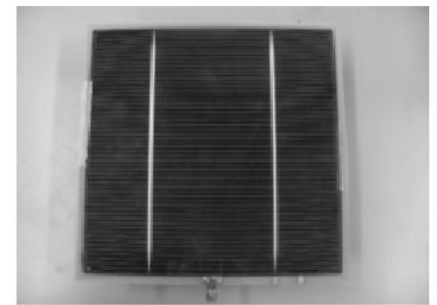

(a) Prototype A

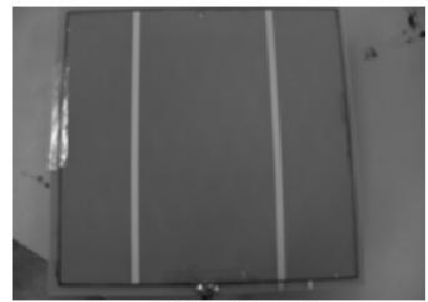

(c) Prototype C

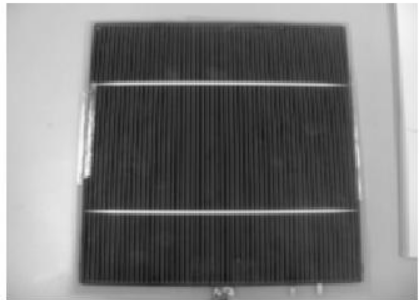

(b) Prototype B

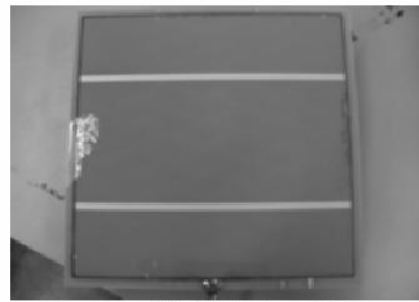

(d) Prototype D
Figure 2. Rear side of the prototypes under investigation

(a) Dense silver-lined grid perpendicular to microstrip feed, Aluminium layer in contact with FR4.

(b) Dense silver-lined grid parallel to microstrip feed, Aluminium layer in contact with FR4.

(c) Dense silver-lined grid perpendicular to microstrip feed and in direct contact with the FR4 substrate.

(d) Dense silver-lined grid parallel to microstrip feed, and in direct contact with the FR4 substrate.

In Prototypes A and B the aluminium layer of the solar cell acts as an RF ground for the antenna. The DC silver line grid over the silicon is also placed densely enough to provide the same function in Prototypes $\mathrm{C}$ and D. Thus the DC and RF function of the proposed solar antenna are intimately linked and a fully integration is achieved.

\section{Results and discussion}

The finite-integration time-domain electromagnetic solver (CST-MWS) was used to simulate the performance of the four models with solar cell as well as the ideal PEC antenna.

The required overlap distance of the patch and the transmission feed line for the optimal coupling was investigated for the ideal patch and the four mentioned models, both with the parameter sweep tool of the CST
Microwave Studio and subsequently with experimental measurement of the prototypes. The patch location with respect to the cell was centered in all cases and the length of the feed overlap was varied from $30 \mathrm{~mm}$ to $0 \mathrm{~mm}$.

Figure 3 shows the measured S11 for the 4 prototypes along with the PEC ground plane. It can be clearly seen that prototypes $\mathrm{A}$ and $\mathrm{B}$ are shifted upward in frequency by 300 $\mathrm{MHz}$ with respect to prototypes $\mathrm{C}$ and $\mathrm{D}$ and the $\mathrm{PEC}$ antenna. They also present a higher gain as shown in Figure 4.

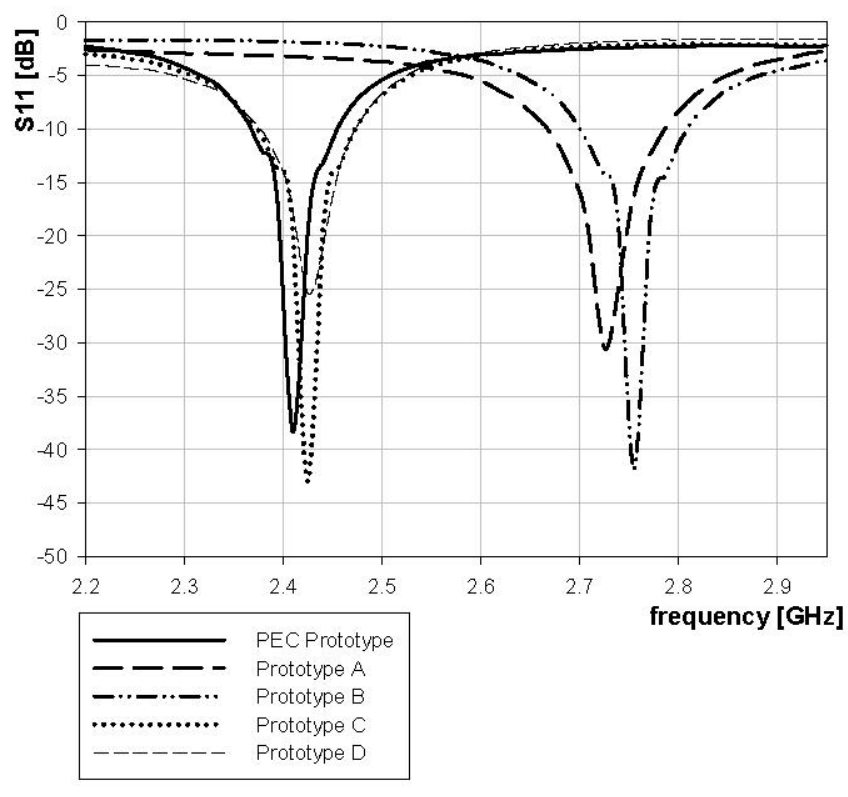

Figure 3. Comparison of S11 for the prototypes investigated and comparison with the ideal PEC antenna.

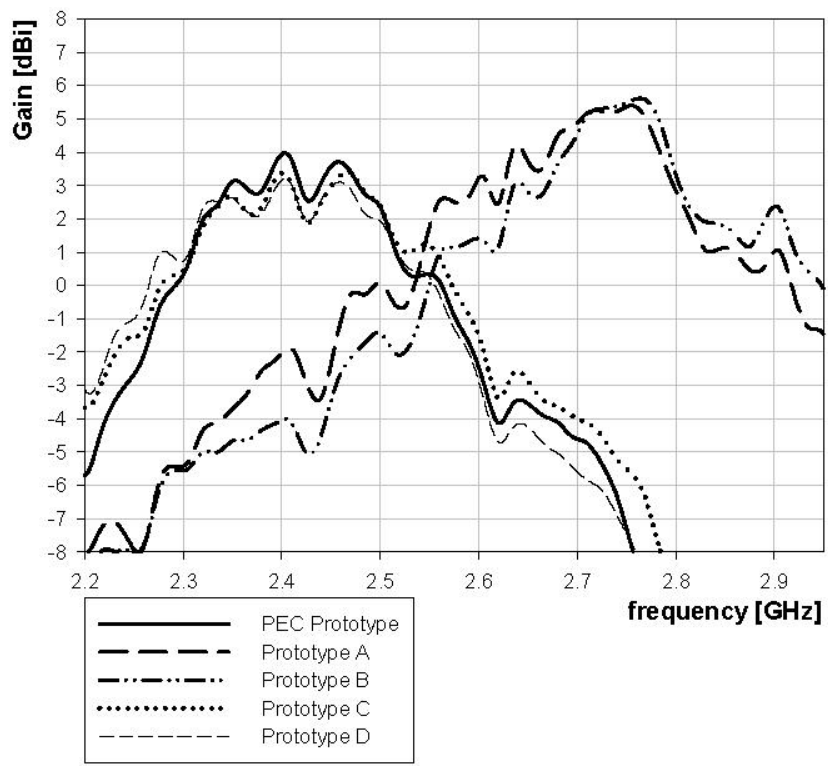

Figure 4. Comparison of the measured gain for the antennas investigated. 


\begin{tabular}{|c|c|c|c|c|c|}
\hline & PEC Prototype & Prototype A & Prototype B & Prototype C & Prototype D \\
\hline $\begin{array}{c}\text { Resonant frequency } \\
(\mathbf{G H z})\end{array}$ & 2.410 & 2.727 & 2.755 & 2.425 & 2.526 \\
\hline Gain (dBi) & 4 & 5.2 & 5.6 & 3 & 2.8 \\
\hline Bandwidth (MHz) & 86 & 117 & 109 & 98 & 95 \\
\hline \% BW & 3.50 & 4.29 & 3.95 & 4.04 & 3.91 \\
\hline
\end{tabular}

Table 1. Summary of measured antenna parameters

A summary of the parameters measured for each prototype at its resonant frequency is given in Table 1 . It can be seen that all the prototypes with the solar cell as ground plane present a higher bandwidth than the PEC antenna.

The measured co-polar radiation pattern for each prototype at its resonant frequency for both principal planes is illustrated in Figure 5.

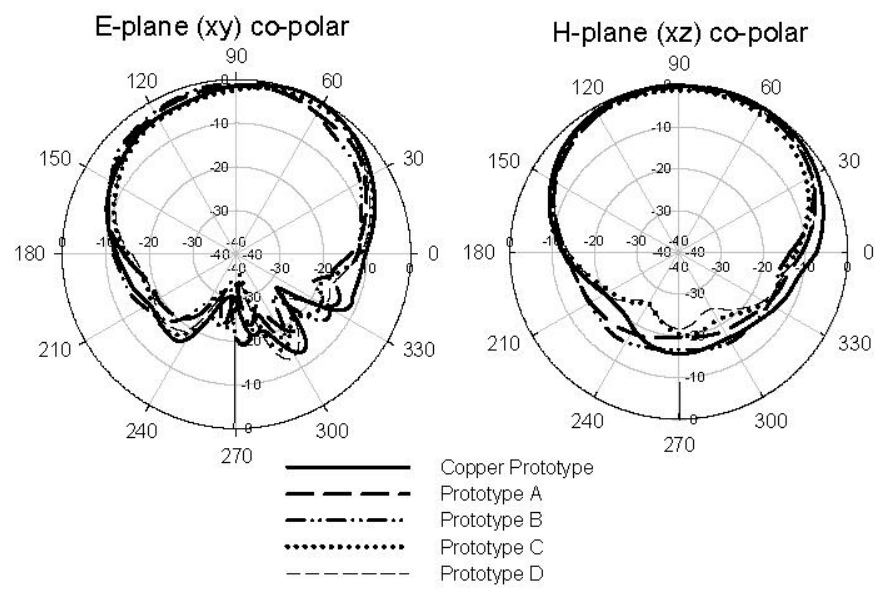

Figure 5. Comparison of measured radiation patterns.

\section{Conclusions}

A proximity-coupled $30 \times 30 \mathrm{~mm}$ square microstrip patch antenna using a $156 \times 156 \mathrm{~mm}$ poly-crystalline solar cell as ground plane is investigated. The performance of the antenna with the four different possible orientations of the solar cell as ground plane was simulated and compared to the ideal PEC ground plane of the same size. These were experimentally verified.

The results suggest that the use of poly-crystalline solar cells as a ground plane, instead of a PEC is feasible for proximity coupled patch antennas.
This could lead to a wide range of applications such as its function in building facade and indoor applications including wireless access points where the active side of the solar cell faces the sun through the window, or for outdoor applications like urban mobile cellular networks, with the FR4 replaced by an optically transparent material.

\section{Acknowledgements}

This project was funded by Science Foundation Ireland.

\section{References}

[1] M. Tanaka, Y. Suzuki, K. Araki and R. Suzuki, "Microstrip antennas with solar cells for microsatellites", Electron. Lett., vol. 31, pp. 263-266, (1996).

[2] S. Vaccaro, J. R. Mosig, P. de Maagt, "Two advanced Solar Antenna SOLANT Designs for Satellinte and Terrestrial Communications", IEEE Trans. Antennas Propagat., vol. AP-51, No. 8, pp. 2028-2034, (2000)

[3] C. Bendel, N. Henze, M.Weitz, P. Hofmann, J. Kirchhof, "Investigations on Planar Antennas with Photovoltaic Solar Cells for Mobile communications", IEEE International Symposium on personal, Indoor and Mobile Radio communication (PIMRC),vol.1, pp. 622626, (2004). 